\title{
Wartość rodzin dzieci z niepełnosprawnością
}

\section{Wstęp}

Rodzina to wspólnota osób, która stanowi podstawową formę życia indywiduRalnego i społecznego. Jest ona naturalnym i niezastąpionym środowiskiem, w którym każda osoba może rozwijać się integralnie na miarę swoich możliwości. Współcześnie zauważalne są liczne zmiany zachodzące w życiu społeczeństw, ale także indywidualnym człowieka. Powszechny relatywizm, a przez silnie zideologizowane środowiska zakwestionowanie podstawowych wartości ma swoje reperkusje w postrzeganiu i realizowaniu życia rodzinnego. Najbardziej widocznym przykładem są liczne formy nacisku i próba zmiany definicji małżeństwa jako związku mężczyzny i kobiety ${ }^{1}$. Polska w ostatnich latach w Europie stała się swoistą wyspą niosącą i zachowującą tradycję podstawowych wartości m.in. rodziny. Nadal stanowi ona „fundamentalny krąg rozwoju i wychowania dziecka, pierwotne źródło międzyludzkich kontaktów oraz płaszczyznę kształtowania się więzi psychicznych z rodzicami i rodzeństwem”2. Realizowanie niniejszego procesu tworzenia rodziny nie jest łatwym zadaniem, szczególnie w kulturze postnowoczesności. Jeszcze trudniejszym zadaniem do spełnienia staje się w rodzinach borykających się z niepełnosprawnością dziecka. Stąd niniejsza refleksja ma na celu nakreślenie sytuacji rodzin z dziećmi z niepełnosprawnością, podkreślenie wartości, jaką stanowią dla środowiska lokalnego, a także dla całego społeczeństwa.

\footnotetext{
* Ks. Dr Andrzej JAsnos - Instytut Pedagogiki, Wydział Nauk Społecznych Katolickiego Uniwersytetu Lubelskiego Jana Pawła II, e-mail: jasnosa@interia.pl, ORCID: 0000-0001-8875-2482.

${ }^{1}$ Por. R. de Mattei, Dyktatura relatywizmu, przekł. P. Toboła-Pertkiewicz, E. Turlińska, Warszawa 2009, s. 36 .

2 J. Szymanowska, Funkcjonowanie rodziny z dzieckiem chorym i niepetnosprawnych $w$ środowisku lokalnym: potrzeby i możliwości pomocy, „Społeczeństwo i Rodzina” 2017, nr 51, s. 100.
} 


\section{Rodzina jest wartością}

Zmiany zachodzące we współczesnym świecie podejmowane są przez licznych badaczy życia społecznego. Analiza "gwałtownie przyśpieszonych zmian w świecie współczesnym i związanych z nimi problemów wskazuje, iż dotyczą one wszystkich sfer życia człowieka, wpływając na życie samej jednostki, jak i społeczności, w których żyje, rozwija się i działa, m.in. rodziny"3. Dlatego potrzeba swoistego powrotu do źródła stanowiącego o wartości także i rodziny oraz ponownego przypominania o nim. Każde prawo stanowione przez człowieka powinno mieć swoje źródło w niezmiennym prawie naturalnym.

Benedykt XVI wskazywał, że „dzisiaj nadal ważne jest, aby człowiek nie dopuszczał, by krępowały go zewnętrzne więzy, takie jak relatywizm, dążenie do władzy i zysku za wszelką cenę, narkomania, nieuporządkowane związki uczuciowe, zamieszanie w kwestii małżeństwa, nieuznawanie ludzkiej istoty na wszystkich etapach jej życia, od początku po naturalny kres, tak jakby w pewnych fazach ludzka istota nie istniała naprawdę. Musimy odważnie przypominać naszym współczesnym, kim jest człowiek i co to jest człowieczeństwo. Wzywam władze państwowe oraz tych, którzy uczestniczą w procesie przekazywania wartości, aby mieli zawsze odwagę mówić prawdę o człowieku"4. Podkreślił również, że „każdy porządek prawny, zarówno krajowy, jak i międzynarodowy, odnajduje swoją zasadność i legitymizację w prawie naturalnym, tym przesłaniu etycznym wpisanym w samą istotę ludzką [...] prawo naturalne stanowi jedyną skuteczną ochronę przed nadużyciami władzy czy manipulacjami ideologicznymi”. Stąd prawo naturalne stoi na straży wszelkich praw stanowionych przez społeczeństwa.

Pewne zbieżne elementy wynikające z prawa naturalnego odnajdujemy w Konstytucji Rzeczypospolitej Polskiej ${ }^{6}$, gdzie artykuł 18 określa „małżeństwo jako związek kobiety i mężczyzny, rodzina, macierzyństwo i rodzicielstwo znajdują się pod ochroną i opieką Rzeczypospolitej Polskiej”'. Oprócz przytoczonego artykułu w obowiązującym prawie państwowym, w artykule 41 ustęp 2, artykule 233 ustęp 1 i Preambule wskazuje się, że rodzina znajduje się pod ochroną i opieką państwa, które także w swojej polityce społecznej i gospodarczej ma obowiązek uwzględniać jej dobro. Rodziny znajdujące się w trudnej sytuacji nie tylko materialnej, ale także społecznej mają zagwarantowane prawo do

${ }^{3}$ M. Opiela, Osoba i rodzina wobec wyzwań cywilizacyjnych. Pedagogia integralnego rozwoju i edukacji w koncepcji ochrony Edmunda Bojanowskiego, Lublin 2019, s. 9.

${ }^{4}$ Benedykt XVI, Pomagajcie ludziom budować lepsze życie. 10.02.2007. Przemówienie do członków papieskiej Akademii Nauk Moralnych i Politycznych, „L'Osservatore Romano” 2007, nr 2, s. 36.

${ }^{5}$ Benedykt XVI, Przemówienie na Papieskim Uniwersytecie Laterańskim 12 lutego 2007, za: R. de Mattei, Dyktatura relatywizmu, s. 39.

${ }^{6}$ Konstytucja Rzeczypospolitej Polskiej z dnia 2 kwietnia 1997 r., Dz.U. 1997 nr 78 poz. 483 ze zm.

7 Tamże, art. 18. 
szczególnej pomocy ze strony władz publicznych ${ }^{8}$. Państwo jest zobowiązane do podejmowania działań umacniających więzi między osobami tworzącymi rodzinę. Dotyczy to więzi między rodzicami a dziećmi, dziećmi a rodzicami, a także między samymi małżonkami ${ }^{9}$. Można więc stwierdzić, że prawo polskie zakłada niezbywalną wartość rodzinny jako tej, która stanowi podstawową komórkę tworzącą i kształtującą społeczeństwo. Widoczne to jest szczególnie w pozytywnej funkcji wychowawczej państwa ${ }^{10}$. Niestety nie jest wolne od niezgodności z prawem naturalnym. Artykuł 38 Konstytucji wskazuje bowiem, że Rzeczpospolita Polska zapewnia każdemu człowiekowi prawną ochronę życia ${ }^{11}$. Jednak takiego prawa odmawia się osobom, kiedy m.in. badania prenatalne lub inne przesłanki medyczne wskazują na duże prawdopodobieństwo ciężkiego i nieodwracalnego ich upośledzenia albo nieuleczalnej choroby zagrażającej ich życiu ${ }^{12}$. Można stwierdzić zatem, że państwo stoi na straży dobra jedynie osób w pełni zdrowych. Jest to zagadnienie, które wywołuje niejednokrotnie ożywioną dyskusję w społeczeństwie, dlatego potrzeba jasnego uregulowania w tej kwestii powracającego do prawa naturalnego, gdzie każda osoba ma prawo do życia od poczęcia do naturalnej śmierci. Każde ustępstwo w tej sprawie jest zaprzeczeniem wartości życia człowieka i sprowadzeniem jego osoby jedynie do materialistycznej użyteczności dla społeczeństwa.

Wizja rodziny wypływająca z prawa naturalnego jako związku mężczyzny i kobiety oraz przysługującego im prawa do zrodzenia i wychowania swojego potomstwa współcześnie jest kwestionowana przez liczne środowiska $\mathrm{w}$ imię zniekształconego prawa do „wolności”. Takiemu działaniu wydają się przeciwstawiać deklaracje młodych osób dotyczące wartości przez nich uznawanych. Potwierdzają to badania przeprowadzone przez Kazimerza Skoczylasa, które m.in. odnosiły się do deklaracji młodzieży, które wartości są dla nich najważniejsze. Mimo widocznego coraz wyraźniejszego nastawienia materialistycznego młodego pokolenia Polaków, wyniki tych badań wskazują jednoznacznie, że nadal najważniejszą wartością jest rodzina ${ }^{13}$. Również wyniki badań deklaracji związanych $\mathrm{z}$ wyborem życia $\mathrm{w}$ przyszłości potwierdzają wysoką ocenę życia rodzinnego, gdyż zdecydowana większość młodzieży planuje swoją przyszłość w małżeństwie ${ }^{14}$.

${ }^{8}$ Zob. tamże, art. 71.

9 Trybunał Konstytucyjny. Wyrok z dnia 18 maja 2005 r., Sygn. akt K 16/04.

${ }_{10}$ Zob. więcej: M. Czachorowski, Rodzina a państwo w wychowaniu dziecka, w: Katolickie wychowanie dziecka. Rodzina, przedszkole, Kościót, red. A. Kiciński, M. Opiela, Lublin 2016, s. 67-75.

${ }^{11}$ Por. Konstytucja Rzeczypospolitej Polskiej art. 38.

12 Por. Dz.U. z 1993 r. nr 17, poz. 78.

${ }_{13}$ Por. K. Skoczylas, Wartości religijno-moralne młodzieży ponadgimnazjalnej Kujaw wschodnich, Włocławek 2016, s. 98.

${ }^{14}$ Niepublikowane wyniki uzyskane w badaniach własnych autora w roku 2018 wśród młodzieży maturalnej wykazują, że $64,11 \%$ badanych deklaruje, że w przyszłości zawrze sakramentalny związek małżeński, 6,13\% planuje swoją przyszłość w związku bez ślubu, 2,19\% w luźnych spotkaniach 
Szeroko rozumiane wartości towarzyszą człowiekowi w każdej dziedzinie jego działalności, począwszy od tych najbardziej prozaicznych po sferę etyki i moralności. Jak zauważa Władysław Zuziak, z wartościami mamy „do czynienia «wszędzie, gdzie przerwana zostaje obojętność, czy też równorzędne relacje pomiędzy rzeczami, wszędzie gdzie jedna rzecz zostaje wybrana lub oceniona wyżej i jest bardziej od innej preferowana»"15. Istotne wydaje się nakreślenie samego pojęcia „wartość", gdyż współcześnie jest ono niejednoznaczne i poddawane wielu deformacjom. Do XIX wieku termin „wartość” był utożsamiany z terminem „dobro", wchodzącym w obszar problematyki moralnej - etyki. Dokonując analizy literatury przedmiotu, nie sposób odnaleźć jedną, wyczerpującą definicję wartości, gdyż każda posiada w sobie jakieś specyficzne cechy zależne od podejścia naukowego, które ją określa. Główne różnice wynikają z podejścia naukowego rozciągającego się od subiektywizmu, przez relatywizm, aż do obiektywizmu i absolutyzmu. Tak szerokie podejście również ma swoje konsekwencje w kształtowaniu się społeczeństw; szczególnie ich kultury. Mieczysław Gogacz wartości definiuje jako trwanie relacji osobowych oraz wynikające z tego skutki. Autor stwierdza, że „wartość jest trwaniem skutku, przyczynowego w człowieku przez podstawowe relacje, łączące go z ludźmi, gdy swym rozumieniem i decyzją człowiek zabiega o trwanie tych relacji jako celu i zadania. To więc, co rozpoznane i akceptowane, trwa dalej, jest wartością: quod intellectum et approbatum continua"16.

Triada klasycznych wartości: prawda, dobro i piękno są najbardziej cenionymi i zasadniczo niezmiennymi historycznie ${ }^{17}$. Zofia Matulka określając wartości zauważa, że mają one „charakter obiektywny, tzn. iż wartością nie jest coś dlatego, że wywołuje u człowieka zainteresowanie, upodobanie, pragnienie posiadania, lecz właśnie dlatego, że jest wartościowe - wywołuje wymienione przeżycia"18. Autorka podkreśla, że aby wartości mogły być urzeczywistnione, „muszą być najpierw rozpoznane przez człowieka, poznane, dzięki czemu wywołują zainteresowanie, uczuciowe zaangażowanie, a następnie dążenie do nich, wybór wyrażający się poprzez świadome decyzje woli. Wola bowiem jest tą władzą człowieka, przez którą przyjmuje on wartości”19. Wartości odgrywają ważną rolę

z wieloma partnerami, 5,25\% chce zostać osobami samotnymi, 2,41\% swoją przyszłość wiąże ze stanem konsekrowanym, a 19,91\% nie potrafi sprecyzować swoich planów na przyszłość. Badanie przeprowadzone na grupie 500 maturzystach.

${ }_{15}$ W. Zuziak, Aksjologia Louis'a Lavelle’a wobec ponowoczesnego kryzysu wartości, Kraków 2012, s. 103.

${ }_{16}$ M. Gogacz, Uwagi do tematu wartości, „Studia Philosophiae Christianae” 1981, t. 17, nr 1, s 203.

${ }_{17}$ Por. A. Jasnos, Wychowanie do harmonii i piękna duchowego w wizji pedagogicznej Edmunda Bojanowskiego, „Zeszyty Naukowe Katolickiego Uniwersytetu Lubelskiego” 2017, nr 4 (240), s. 173.

${ }_{18}$ Z. Matulka, Wartości u podstaw wychowania personalistycznego, w: Wychowanie personalistyczne, red. F. Adamski, Kraków 2005, s. 227.

19 Tamże, s 226-227. 
w procesie wychowania, które również ma za zadanie naukę rozpoznawania ich i rozwijanie umiejętności dokonywania dobrego wyboru. Trzeba zauważyć, że „prawdziwe wychowanie, nieskażone żadnym rodzajem interesowności, zmierza zawsze do zorientowania człowieka na wartości uniwersalne, które są jednakowo pożądane i ostatecznie korzystne tak dla jednostki, jak i dla społeczności ludzkich, ale wymaga ono jakiegoś wysiłku także ze strony wychowanka"20.

Syntetyczną definicję wartości podaje Mieczysław Łobocki, który uważa, że „wartością jest to wszystko, co uchodzi za ważne i cenne dla jednostki i społeczeństwa, co jest godne pożądania i może stanowić cel dążeń ludzkich (...) akceptowana wartość nie może pozostawać w sprzeczności z dobrem wspólnym”21. Odnosząc powyższą definicję do refleksji dotyczącej wartości rodziny można stwierdzić, że jest ona istotną zarówno dla jednostki, jak i dla społeczeństwa. Rodzina rozumiana jako związek kobiety i mężczyzny wraz z ich potomstwem, nadal w społeczeństwie polskim jest ważna i cenna dla każdego człowieka, gdyż w niej może dokonać się jego integralny rozwój. Jest bardzo ważna także dla społeczeństwa, skoro prawo stanowione otacza ją szczególną opieką i wsparciem. Jest ona pożądana i stanowi życiowy cel młodych ludzi, co potwierdzają badania naukowe, jest akceptowana przez większość i przede wszystkim nie stoi w sprzeczności z dobrem wspólnym i prawem naturalnym.

Przyjęcie rozumienia rodziny jako wartości prowadzi do przyjmowania dobrych i pożądanych działań na rzecz jej rozwoju i wsparcia. Jednak mimo powszechnego przyjęcia stanowiska, iż rodzina jest wartością dla jednostki i społeczeństwa, pojawiają się liczne ataki i próby zakwestionowania istoty małżeństwa i rodziny. Przykładem tego jest tzw. Konwencja stambulsk $a^{22}$ zakładająca „wykorzenianie tradycji, aby wprowadzać zamierzone zmiany społeczne i kulturowe w zakresie postrzegania płci [...] przez genderową edukację dotyczącą niestereotypowych ról społeczno-kulturowych"²3.

Powyższa refleksja daje postawy do stwierdzenia, że problematyka rodziny, m.in. jej miejsca w społeczeństwie, w hierarchii wartości, jak również samego jej definiowania i jej roli stanowi nadal aktualne wyzwanie dla badaczy wielu dziedzin naukowych. Kultura ponowoczesności prowadząca do zmiany tradycyjnego modelu rodziny i zakwestionowania jej wartości powinna pobudzać do jeszcze bardziej zintensyfikowanych działań promocyjnych. Wymaga to wskazania rzetelnych podstaw, przede wszystkim antropologicznych oraz

\footnotetext{
${ }^{20} \mathrm{~J}$. Lach-Rosocha, Problemy wychowania moralnego w duchu pedagogiki kultury. W: Pedagogika kultury - wychowanie do wyboru wartości, red. tenże, Kraków 2003, s. 47.

${ }^{21}$ M. Łobocki, Wartości tworzywem wychowania, w: Wychowanie chrześcijańskie a kultura, red. M. Nowak, T. Ożóg, Lublin 2000, s. 72.

${ }^{22}$ Konwencja Rady Europy o zapobieganiu i zwalczaniu przemocy wobec kobiet i przemocy domowej, sporządzona w Stambule dnia 11 maja 2011 r., Dz.U. 2015 poz. 961.

${ }^{23}$ M. Opiela, Osoba i rodzina wobec wyzwań cywilizacyjnych, s. 74.
} 
opartej na nich definicji rodziny wypływającej z prawa naturalnego, jak również z przyjęcia wartości niezbywalnych jak dobro, prawda i piękno.

Można przypuszczać, że skoro zauważalne są tak liczne trudności w sferze samego określania rodziny jako wartości, jeszcze większe trudności będą występować $\mathrm{w}$ próbie ukazania wartości rodziny $\mathrm{z}$ dzieckiem $\mathrm{z}$ niepełnosprawnością. Wspomniany wcześniej fakt odbierania prawa do życia osobie z niepełnosprawnością wskazuje już istotną trudność w dostrzeżeniu wartości życia ludzkiego, które w jakiejś sferze jest niesprawne. Skoro osoba jeszcze nienarodzona nie stanowi wartości dla społeczeństwa, tylko przez wzgląd na prawdopodobną niepełnosprawność, to warto zadać pytanie, jaką wartość będzie stanowić taka osoba po urodzeniu?

\section{Wartość osoby z niepełnosprawnością}

Analizując współczesną sytuację życiową rodziny, można dostrzec wiele zagrożeń wynikających głównie z przemian kulturowych. Szerzący się styl konsumpcyjny życia niejednokrotnie sprowadza osobę jedynie do sfery użyteczności, zaburzając relacje międzyludzkie. Jak zauważa Aneta Rayzacher-Majewska, jakość relacji międzyosobowych, w tym rodzinnych, ma wpływ na funkcjonowanie innych społeczności. Wynika to stąd, że „rodzina stanowi szkołę życia, bowiem na jej gruncie nabywa się umiejętności współdziałania, odpowiedzialności, troski, pomocy, przebaczenia"24. Jeszcze większe trudności i komplikacje w prawidłowej realizacji zadań i funkcji zauważalne są, jeżeli podda się analizie sytuację rodziny borykającej się z niepełnosprawnością dziecka. Joanna Szymanowska stwierdza, że „odmiennie przebiega także sam proces wychowania młodego człowieka, w pewnym sensie i do pewnego stopnia jest on bowiem postrzegany jako członek rodziny znajdujący się w sytuacji wyjątkowej [...] niepełnosprawność dziecka staje się istotnym źródłem licznych napięć oraz zaburzeń w prawidłowym funkcjonowaniu środowiska rodzinnego, czynnikiem wywołującym zmiany $\mathrm{w}$ interakcjach zachodzących zarówno pomiędzy członkami rodziny, jak też w relacjach $\mathrm{z}$ otoczeniem społecznym" ${ }^{25}$. Pojawienie się dziecka z niepełnosprawnością powoduje istotne zmiany w życiu całej rodziny. Dotyczą one wszystkich członków rodziny, jednak jak zauważają badacze zagadnienia „szczególnie dotkliwie są odczuwane przez matki dzieci, bowiem to na ich barki spada niemal cały problem dotyczący opieki i wychowania $w$ tych zupełnie zmienionych

24 A. Rayzacher-Majewska, Znaczenie wspólnoty w życiu rodziców dziecka z niepełnosprawnościa, w: Nieoceniona wartość osoby. 25 lat Wspólnoty Wiara i Światło w Bochni, red. A. Jasnos, M. L. Opiela, Lublin 2018, s. 131.

${ }^{25}$ J. Szymanowska, Funkcjonowanie rodziny z dzieckiem, dz. cyt., s. 101. 
warunkach"26. Trzeba także zaznaczyć często występujące zjawisko porzucania przez mężczyzn kobiet w sytuacji pojawienia się dziecka $\mathrm{z}$ niepełnosprawnością. Tym bardziej to właśnie one odczuwają nie tylko stres związany z pojawianiem się dziecka, ale również obawy przed odrzuceniem najbliższych.

W ostatnich latach znacznie wzrosła świadomość społeczna dotycząca niepełnosprawności, jednak nadal uważana jest ona jako swoiste obciążenie nie tylko dla rodziny, ale również dla społeczeństwa. W tej kwestii wydaje się istotne nakreślenie filozoficznej koncepcji wartości człowieka jako osoby. Jak zauważa Maria Opiela „bez względu na stan zdrowia, sprawność czy status społeczny rodziny od poczęcia potrzebuje on wychowania i wspólnoty dla aktualizacji swego osobowego potencjału"27.

Do podjęcia adekwatnych działań wobec wsparcia rodzin z osobą z niepełnosprawnością, potrzeba przyjęcia realistycznej teorii człowieka jako osoby. Adekwatna antropologia, która „niesie ponadczasową prawdę o człowieku jako takim; człowieku, który jest tym, kim jest, i takim jakim jest, niezależnie od warunków życia, możliwości działania oraz poznawania"z8 jest niezbędna do docenienia roli osób z niepełnosprawnością, jaką odgrywają w społeczeństwie.

Jej podstawę stanowi „norma personalistyczna - naczelna zasada etyczna, według której każdego człowieka należy traktować jako podmiot i cel, nigdy jako przedmiot, a właściwie odniesienie do niej stanowi miłośćn'29. Osoba ludzka powinna stanowić wyznacznik wszelkich rozwiązań filozoficznych, teologicznych, społecznych, etycznych czy artystycznych ${ }^{30}$. Według Piotra Tomasza Goliszka „Współcześnie personalizm stał się fenomenem ogólnoludzkim, tworzącym «nową» cywilizację rozumienia i interpretację wszechbytu. Jako system daje on «mocną» filozofię społeczną, dostarcza pozytywnego programu humanizacji świata przez zwrócenie uwagi na godność osoby ludzkiej, na jej wymiar duchowy oraz godność ludzkich wspólnot"31.

Przyjmując i podkreślając założenia antropologii adekwatnej, osoba z niepełnosprawnością nie staje się obciążeniem dla społeczeństwa, ale darem jako ta, przez którą osoby pełnosprawne mogą realizować swoje człowieczeństwo.

Nieodłączna sfera życia ludzkiego - moralno-etyczna, wyróżnia go ze świata stworzonego, sytuując w nim osobę jako cel, a nie przedmiot działań. Magda-

\footnotetext{
${ }^{26}$ M. Sekułowicz, Problematyka funkcjonowania rodzin dzieci niepełnosprawnych, „Teraźniejszość - Człowiek - Edukacja” 1998, nr 1, s. 61.

${ }_{27}$ M. Opiela, Znaczenie wczesnej edukacji w integralnym rozwoju i wychowaniu osoby - wymiar indywidualny i wspólnotowy, w: Nieoceniona wartość osoby. 25 lat Wspólnoty Wiara i Światło w Bochni, red. A. Jasnos, M. L. Opiela, Lublin 2018, s. 116.

${ }_{28}$ M. Mruszczyk, Człowiek w „antropologii adekwatnej” Karola Wojtyły, Katowice 2010, s. 9.

${ }^{29}$ M. Opiela, Znaczenie wczesnej edukacji w integralnym, s. 117.

${ }_{30}$ Por. R.T. Flewelling, Studia personalizmu amerykańskiego, „Personalizm” 2004, nr 6, s. 31-54.

${ }^{31}$ P.T. Goliszek, Personalistyczny wymiar katechezy, Lublin 2016, s. 81.
} 
lena Mruszczyk podkreślając istotę podejmowanego działania stwierdza, że „człowiek, uświadamiając sobie, że jest sprawcą działania, i przeżywając swą sprawczość czynów, wraz z nią przeżywa wartość moralną czynów. Dzięki temu uświadamia sobie, że jest sprawcą wartości moralnych, dobra lub zła moralnego. Sprawczość wyznacza charakterystyczny, twórczy rys ludzkiego, osobowego sposobu działania, a zatem również istnienia"32. W tym kontekście, każdy człowiek, nie tylko rodzice dziecka z niepełnosprawnością, podejmując działanie, jakim jest przyjęcie go i wspieranie w integralnym rozwoju na miarę jego możliwości, ma możliwość realizowania swojego istnienia jako osoba ludzka. Szczególnie współcześnie, uznając podmiotowość osoby z niepełnosprawnością, człowiek wykracza poza świat materialny, a wkracza w pełnię realizacji powierzonego mu życia. Cytowana autorka podkreśla, iż takie podejście to wkraczanie w świat wartości, które wyróżniają człowieka, gdyż „swej sprawczości człowiek zawdzięcza to, że żyje nie tylko w świecie przyrody, ale mając kontakt z rzeczywistością moralną, żyje również w świecie wartości" ${ }^{\prime 3}$.

Można więc stwierdzić, że przyjęcie i uznanie osoby z niepełnosprawnością przez pełnosprawnych członków społeczeństwa daje możliwość całej grupie doświadczyć pełni człowieczeństwa, gdyż jest to akt nacechowany pozytywną wartością moralno-etyczną. Takie podejście podkreślał niejednokrotnie Karol Wojtyła, stwierdzając, że „doświadczenie moralności musi nas interesować w szczególny sposób, gdyż wartości moralne - dobro i zło -stanowią nie tylko wewnętrzną właściwość ludzkich czynów, ale mają również to do siebie, że człowiek właśnie jako osoba poprzez te moralnie dobre lub złe czyny sam staje się dobry lub zły. Dynamicznie więc, czyli egzystencjalnie, rzecz ujmując, można powiedzieć, iż zarówno w punkcie wyjścia tych wartości, jak też w ich punkcie dojścia jawi się osoba. Jawi się bardziej jeszcze niż poprzez sam «czysty» czyn" ${ }^{\text {"4 }}$. Wraz z obecnością człowieka z niepełnosprawnością rodzina, najbliższe środowisko, a także szeroko rozumiane społeczeństwo staje się zdolne do przekraczania materialnego i doczesnego horyzontu swoich działań. Przede wszystkim otwiera go na urzeczywistnianie wartości wyższej kategorii, przez co wszelkie działania skoncentrowane są na człowieku i „prowadzi do personalizacji, uczłowieczenia organizacji, wspólnoty czy wręcz całego systemu"35.

Warto również zasygnalizować, że problematyka wsparcia społecznego osoby z niepełnosprawnością szczególnie ważna jest dla ich rodziców i rodzeństwa. Wielu badaczy „podkreśla zależność zachodzącą pomiędzy wysokim poziomem wsparcia społecznego, a obniżaniem się poziomu stresu wywołanego koniecznością nieustannej opieki nad niepełnosprawnym dzieckiem. Ma to

${ }^{32}$ M. Mruszczyk, Człowiek w „antropologii adekwatnej”, s. 145.

${ }_{33}$ Tamże, s. 146.

${ }^{34}$ K. Wojtyła, Osoba i czyn oraz inne studia antropologiczne, Lublin 2000, s. 61.

${ }_{35}$ T. Janik, Człowiek jako najważniejszy kapitał wspólnoty, w: Nieoceniona wartość osoby. 25 lat Wspólnoty Wiara i Światło w Bochni, red. A. Jasnos, M. L. Opiela, Lublin 2018, s. 89. 
duże znaczenie dla przebiegu procesu radzenia sobie rodziców"36. Uznanie ich dziecka $\mathrm{z}$ niepełnosprawnością jako pełnowartościowej osoby przez najbliższe środowisko, jak również całe społeczeństwo, jest niezmiernie istotne, by rodzice mogli czuć się również pełnowartościowymi członkami wspólnoty. Niezmiernie ważne są tu zmiany w przedstawianiu osób z niepełnosprawnością nie jako swoistego balastu dla innych, ale jako pewien potencjał dla społecznego rozwoju.

\section{Rodzina "niepełnosprawna”}

Każde dziecko jest wyjątkowym członkiem rodziny, za którego pełną odpowiedzialność ponoszą rodzice mający niezbywalne prawo do wychowania i opieki nad nim. Tym bardziej, wychodząc z założeń także prawa stanowionego, rodzice dziecka z niepełnosprawnością posiadają prawo do wsparcia ich w tych działaniach. Każda choroba dziecka budzi w rodzicach ich wielki niepokój, a niejednokrotnie też poczucie winy ${ }^{37}$. Jeżeli więzi rodzinne są słabe, zdarza się, iż choroba czy niepełnosprawność dziecka doprowadza do wzajemnego obwiniania się za dyskomfort życia rodzinnego, bądź także do rozpadu rodziny ${ }^{38}$. Jak zauważa Joanna Szymanowska „na jakość opieki wpływają niewątpliwie warunki materialne rodzin wychowujących dzieci wymagające specyficznego odżywiania lub usprawniania. Pośród czynników zagrażających prawidłowemu wspomaganiu dziecka i rodziny wymienia się głównie ograniczony dostęp do specjalistycznej pomocy i opieki, trudności w zaopatrywaniu w odpowiednie leki i sprzęt rehabilitacyjny, brak środków finansowych na likwidację barier architektonicznych, w komunikowaniu się czy technicznych"39, jak również ocenę społeczną specyficznej sytuacji rodziny.

Niejednokrotnie rodzina osoby z niepełnosprawnością; szczególnie rodzice, ale także rodzeństwo, odczuwa poczucie bycia "rodziną niepełnosprawną", czyli mniej wartościową w społeczeństwie. W takich rodzinach zachodzi niezaprzeczalnie potrzeba wzmacniania oraz rozbudzania utraconych wartości, szczególnie „poczucia godności, zaburzonych społecznych kontaktów, realizacji potrzeby samodzielności, sukcesu, odnajdowania sensu życia"40. W działaniach społecznych nie chodzi o swoiste „zaczarowywanie rzeczywistości” i niezauważanie niepełnosprawności dziecka, włączające je we wszystkie dziedziny życia społecznego, ale przede wszystkim o dostrzeżenie osoby i docenienie jej wartości. Adekwatne wsparcie integralnego rozwoju osoby z niepełnosprawnością polega

\footnotetext{
${ }^{36}$ M. Sekułowicz, Problematyka funkcjonowania rodzin, s. 75.

${ }^{37}$ Por. A. Kwak, Chore dziecko w domu, „Problemy Rodziny” 1998, nr 4, s. 28.

${ }^{38}$ Por. A. Pietrzyk, „Ta choroba” w rodzinie. Psycholog o raku, Kraków 2006, s. 24.

${ }^{39}$ J. Szymanowska, Funkcjonowanie rodziny z dzieckiem chorym i niepelnosprawnym, s. 103.

${ }^{40}$ Tamże, s. 106.
} 
przede wszystkim na uznaniu jej jako pełnoprawnego członka społeczeństwa, posiadającego niezbywalne prawo do życia i rozwoju na miarę swoich możliwości. Wsparcie rodziny jako tego pierwszego środowiska pomocowego wymaga podejścia zindywidualizowanego, w ramach którego postulowane byłyby „działania komplementarne, dostosowane do potrzeb i możliwości konkretnych osób i ich całych środowisk rodzinnych, pozwalających na likwidację barier społecznych, kulturowych, psychologicznych i ekonomicznych" ${ }^{31}$.

Instrumenty polityki społecznej w obszarze pomocy rodzinom $\mathrm{z}$ osobą $\mathrm{z}$ niepełnosprawnością, wynikające $\mathrm{z}$ ustawy z dnia 4 listopada $2016 \mathrm{roku}$ o wspieraniu kobiet w ciąży i rodzin „Za życiem”"42, na pewno stanowią pewien pozytywny „krok” uczyniony w kierunku poprawy nastawienia społecznego wobec rodzin z osobą z niepełnosprawnością, jak również ich sytuacji. Jednakże autor artykułu ma wrażenie, iż wprowadzanie jakichkolwiek działań pomocowych wobec osób z niepełnosprawnością będzie jedynie swoistym „rozgrzeszeniem" braku działań zmierzających do ochrony życia od poczęcia, również osób z prawdopodobną niepełnosprawnością. Także brak uwzględniania rodzin $\mathrm{z}$ osobami $\mathrm{z}$ niepełnosprawnością $\mathrm{w}$ debatach o rodzinie, stanowi swoistą marginalizację i wprowadzanie tych rodzin w poczucie bycia „niepełnosprawną" czy „niepełnoprawną".

\section{Zakończenie}

Wartości stanowią dla człowieka istotny punkt odniesienia, jak również determinują one jego działanie. Lucyna Drenda poszukując odpowiedzi na pytanie czym jest wartość, stwierdza, że „kategoryzując ją oraz doszukując się jej źródeł, jednostka jest w stanie lepiej zrozumieć pojęcie, którym posługuje się na co dzień w sposób dość automatyczny, podstawiając pod nie zrutynizowane i zinstytucjonalizowane znaczenia. Elastyczność i pojemność pojęcia wartości niewątpliwie nie zachęca współczesnych pokoleń do dopisywania kolejnych rozdziałów w historii jej definiowania. Pragmatyczne utożsamianie wartości w ogóle z wartością użytkową jest swoistą ucieczką przed wachlarzem wieloznaczności, jaki otwiera perspektywa analizy aksjologicznej"ł3. Autorka zauważa również, że „«niewyobrażalnym» jest życie oraz trwanie samego społeczeństwa bez odwoływania się do wartości, a jednak «wyobrażalnym» dla jednostek jest tworzenie teorii i zarazem stosowanie w życiu zasad, które są tych wartości

\footnotetext{
41 Tamże, s. 109.

42 Por. Dz. U. 2016, poz. 1860.

43 L. Drenda, Teoria wartości, wartość teorii, „Zeszyty Naukowa Uniwersytetu Ekonomicznego w Katowicach”, 2016, nr 259, s. 47.
} 
pozbawione"44. Pewnie z tego powodu zagadnienie wartości osoby z niepełnosprawnością, a tym samym wartości rodziny z osobą z niepełnosprawnością, nadal jest aktualne. Widoczne są także i potrzebne istotne zmiany, głównie w podkreśleniu ich znaczenia w społeczeństwie.

Autor ma świadomość, że niniejszy artykuł nie wyczerpuje wszystkich aspektów zagadnienia wartości rodziny z osobą z niepełnosprawnością. Stanowi on jedynie zwrócenie uwagi na istotne trudności w postrzeganiu osoby z niepełnosprawnością, nieścisłości w prawie stanowionym i próbami wsparcia rodzin, jak również na konieczność przyjęcia adekwatnej antropologii w kształtowaniu systemów pomocowych. Autor utożsamia się z koncepcją chrześcijańskiego personalizmu, widząc w nim pozytywny fundament wszelkich działań skierowanych ku człowiekowi. Pozwala on dostrzec przede wszystkim osobę i uznać ją jako równą innym istotę.

Mając świadomość istnienia w Polsce rodzin nie tylko chrześcijańskich, potrzeba promocji personalizmu jako systemu filozoficznego, w którym każdy człowiek może odkryć swoją wartość. Jean Vanier założyciel wspólnot „Wiara i Światło” wskazuje, że „każdy z nas powinien odkryć swą własną słabość. Trzeba nauczyć się nią mądrze kierować, odkrywając cel naszego życia. Ci, którzy sami mają jakąś słabość, mogą znacznie lepiej zrozumieć cierpienie innej osoby [...] piękno istoty ludzkiej polega na tym, aby zaakceptować się takim, jakim się jest [...] to wówczas odkrywamy, że jesteśmy kochani i cenni w oczach Boga. Być może nie jesteśmy przeznaczeni do wielkich rzeczy na tym świecie, do błyszczenia w świetle jupiterów, ale z pewnością jesteśmy stworzeni, aby kochać, kochać również samych siebie, tu, gdzie się znajdujemy, takimi, jacy jesteśmy, ze wszystkimi swoimi słabościami. Jesteśmy stworzeni do przyjęcia miłości, aby dzięki temu móc wyrażać istniejące w nas życie"45.

Każda osoba ma swój wyjątkowy potencjał do zrealizowania. Abstrahując od światopoglądu i przyjmowanych wartości, warto zwrócić uwagę na pewną nieścisłość istniejącą w naszym społeczeństwie. Komórka żeńska i męska ma potencjał zjednoczenia się. Embrion, komórka (czy w niektórych środowiskach „zlepek komórek”), osoba w łonie matki ma potencjał rozwoju i narodzin. Dziecko ma potencjał stać się wyjątkowym dorosłym, mała dziewczynka ma potencjał stać się wyjątkową kobietą, mały chłopiec ma potencjał stać się wyjątkowym mężczyzną. Osobom z prawdopodobną niepełnosprawnością odbiera się ich prawo „potencjału”.

44 Tamże, s. 47.

${ }^{45}$ J. Vanier, Depresja - dlaczego?, tłum. Z. Piątkowska, Katowice 2001, s. 85-87. 


\section{Bibliografia}

Benedykt XVI, Pomagajcie ludziom budować lepsze życie. 10.02.2007. Przemówienie do członków papieskiej Akademii Nauk Moralnych i Politycznych, "L'Osservatore Romano" 2007, nr 2, s. 36.

Czachorowski M., Rodzina a państwo w wychowaniu dziecka, w: Katolickie wychowanie dziecka. Rodzina, przedszkole, Kościół, red. A. Kiciński, M. Opiela, Lublin 2016, s. 67-75.

De Mattei R., Dyktatura relatywizmu, przekł. P. Toboła-Pertkiewicz, E. Turlińska, Warszawa 2009.

Drenda L., Teoria wartości, wartość teorii, „Zeszyty Naukowa Uniwersytetu Ekonomicznego w Katowicach", 2016, nr 259, s. 39-48.

Flewelling R.T., Studia personalizmu amerykańskiego, „Personalizm” 2004, nr 6, s. 31-54.

Goliszek P.T., Personalistyczny wymiar katechezy, Lublin 2016.

Janik T., Człowiek jako najważniejszy kapitał wspólnoty, w: Nieoceniona wartość osoby. 25 lat Wspólnoty Wiara i Światło w Bochni, red. A. Jasnos, M. L. Opiela, Lublin 2018, s. 75-90.

Jasnos A., Wychowanie do harmonii i piękna duchowego w wizji pedagogicznej Edmunda Bojanowskiego, „Zeszyty Naukowe Katolickiego Uniwersytetu Lubelskiego” 2017, nr 4 (240), s. 173-188.

Konstytucja Rzeczypospolitej Polskiej z dnia 2 kwietnia 1997 r., Dz. U. 1997 nr 78 poz. 483 ze zm.

Kotłowski K., Filozofia wartości a zadania pedagogiki, Wrocław-Warszawa-Kraków 1968.

Kwak A., Chore dziecko w domu, „Problemy Rodziny” 1998, nr 4, s. 27-30.

Lach-Rosocha J., Problemy wychowania moralnego w duchu pedagogiki kultury, w: Pedagogika kultury - wychowanie do wyboru wartości, red. tenże, Kraków 2003, s. 37-56.

Łobocki M., Wartości tworzywem wychowania, w: Wychowanie chrześcijańskie a kultura, red. M. Nowak, T. Ożóg, Lublin 2000.

Matulka Z., Wartości u podstaw wychowania personalistycznego, w: Wychowanie personalistyczne, red. F. Adamski, Kraków 2005.

Mruszczyk M., Człowiek w "antropologii adekwatnej” Karola Wojtyły, Katowice 2010.

Opiela M., Osoba i rodzina wobec wyzwań cywilizacyjnych. Pedagogia integralnego rozwoju iedukacji w koncepcji ochrony Edmunda Bojanowskiego, Lublin 2019.

Opiela M., Znaczenie wczesnej edukacji w integralnym rozwoju i wychowaniu osoby - wymiar indywidualny i wspólnotowy, w: Nieoceniona wartość osoby. 25 lat Wspólnoty Wiara i Światło w Bochni, red. A. Jasnos, M. L. Opiela, Lublin 2018, s. 115-130.

Pietrzyk A., "Ta choroba" w rodzinie. Psycholog o raku, Kraków 2006.

Rayzacher-Majewska A., Znaczenie wspólnoty w życiu rodziców dziecka z niepełnosprawnościq w: Nieoceniona wartość osoby. 25 lat Wspólnoty Wiara i Światło w Bochni, red. A. Jasnos, M. L. Opiela, Lublin 2018, s. 131-142.

Sekułowicz M., Problematyka funkcjonowania rodzin dzieci niepełnosprawnych, „Teraźniejszość Człowiek - Edukacja" 1998, nr 1, s. 61-82.

Skoczylas K., Wartości religijno-moralne młodzieży ponadgimnazjalnej Kujaw wschodnich, Włocławek 2016.

Szymanowska J., Funkcjonowanie rodziny z dzieckiem chorym i niepełnosprawnych w środowisku lokalnym: potrzeby i możliwości pomocy, "Społeczeństwo i Rodzina” 2017, nr 51, s. 100-116.

Trybunał Konstytucyjny. Wyrok z dnia 18 maja 2005 r., Sygn. akt K 16/04.

Vanier J., Depresja - dlaczego? tłum. Z. Piątkowska, Katowice 2001.

Wojtyła K., Osoba i czyn oraz inne studia antropologiczne, Lublin 2000.

Zuziak W., Aksjologia Louis'a Lavelle'a wobec ponowoczesnego kryzysu wartości, Kraków 2012.

Gogacz M., Uwagi do tematu wartości, „Studia Philosophiae Christianae” 1981, t. 17, nr 1, s. 200-209. 


\section{Streszczenie}

Rodzina to wspólnota osób, która stanowi podstawową formę życia indywidualnego i społecznego. Jest ona naturalnym i niezastąpionym środowiskiem, w którym każda osoba może rozwijać się integralnie na miarę swoich możliwości. Współcześnie zauważalne są liczne zmiany zachodzące w życiu społeczeństw, ale także indywidualnym człowieka. Powszechny relatywizm, a przez silnie zideologizowane środowiska zakwestionowanie podstawowych wartości ma swoje reperkusje w postrzeganiu i realizowaniu życia rodzinnego. Najbardziej widocznym przykładem są liczne formy nacisku i próba zmiany definicji małżeństwa jako związku mężczyzny i kobiety, jak również kwestionowanie podstawowego prawa do życia od poczęcia do naturalnej śmierci. Polska w ostatnich latach w Europie stała się swoistą wyspą niosącą i zachowującą tradycję podstawowych wartości m.in. rodziny. Realizowanie procesu tworzenia rodziny nie jest łatwym zadaniem, szczególnie $\mathrm{w}$ kulturze postnowoczesności. Jeszcze trudniejszym zadaniem do spełnienia staje się $\mathrm{w}$ rodzinach borykających się z niepełnosprawnością dziecka. Stąd niniejsza refleksja ma na celu nakreślenie sytuacji rodzin z dziećmi z niepełnosprawnością, podkreślenie wartości.

Słowa klucze: rodzina, niepełnosprawność, wartość, wsparcie instytucjonlne

\section{Value of families of children with disabilities}

\section{Summary}

The family is a community of people, which is the basic form of individual and social life. It is a natural and irreplaceable environment in which every person can develop integrally according to their capabilities. Nowadays, there are numerous changes taking place in the life of societies, as well as individual human beings. Universal relativism, and through strongly ideologized environments, the questioning of fundamental values has its repercussions in the perception and implementation of family life. The most prominent examples are the numerous forms of pressure and the attempt to change the definition of marriage as a union of man and woman, as well as questioning the basic right to life from conception to natural death. Poland in recent years in Europe has become a kind of island carrying and preserving the tradition of basic values, including families. The process of creating a family is not an easy task, especially in post-modern culture. An even more difficult task is to be fulfilled in the families struggling with the child's disability. Therefore, this reflection aims to outline the situation of families with children with disabilities, emphasizing values.

Keywords: family, disability, value, institutional support 